\title{
Pengaruh Jumlah Sudu Turbin Angin Savonius Terhadap Unjuk Kerja Generator (Single Phase) Magnet Permanen NdFeB
}

\author{
Anggito P. Tetuko ${ }^{1}$, Candra Kurniawan ${ }^{1,2}$, Sunardi $^{2}$, Ahmad Wahid $^{2}$ dan \\ Perdamean Sebayang ${ }^{1,2, *}$ \\ ${ }^{\text {IP }}$ usat Penelitian Fisika - LIPI, Gd. 440 Kawasan PUSPIPTEK, Tangerang Selatan, Indonesia \\ ${ }^{2}$ Program Studi Teknik Mesin, Universitas Pamulang, Jl. Surya Kencana No. 1, Tangerang Selatan, Indonesia \\ E-mail: *sebayang.perdamean@gmail.com
}

\author{
Masuk:22 Agustus 2017 Direvisi : 7 September 2017 Disetujui : 20 September 2017
}

\begin{abstract}
Abstrak: Telah berhasil dibuat disain dan konstruksi turbin angin savoniuspada generator (single phase)magnet permanen $\mathrm{NdFeB}$. Variasi jumlah sudu turbin masing-masing dibuat sebanyak 4, 8 dan 16 buah, dengan sumber fluida(angin) yangberasaldari turbo fan $(220 \mathrm{~V} / 50 \mathrm{~Hz}-98 \mathrm{~W})$. Pada penelitian ini akan dilihat korelasi antara kecepaatan angin terhadap kecepatan putar generator, output tegangaan tanpa dan dengan beban lampu LED5W, arus listrik dan daya listrik yang dihasilkan generator tersebut. Hasil unjuk kerjagenerator (single phase)magnet permanen NdFeBterhadap pengaruh jumlah sudu turbin relatif linier, baik terhadap kecepatan putar generator, output tegangan, arus dan daya listrik. Korelasi ini menunjukkan bahwa kondisi optimum diperoleh pada kecepatan angin $6,5 \mathrm{~m} / \mathrm{s}$ dan jumlah sudu turbin sebanyak 16 buah, masing-masing menghasilkan kecepatan putar generator, output tegangan tanpa dan dengan beban, arus dan daya listrik adalah 120rpm, 44,3V, 109,8V, 100mA dan 4W. Generator (single phase)magnet permanen NdFeByang dihasilkan dapat digunakan sebagai lampu darurat terutama pada jalan tol.
\end{abstract}

Kata kunci: sudu turbin, magnet $\mathrm{NdFeB}$, generator single phase, kecepatan angin, daya listrik

\begin{abstract}
The wind turbine(Savonius type)-generator(single phase) permanent magnet (NdFeB) systemhave been desained, constructed and tested. The variation of the blades used were 4, 8, and 16 respectively, where the fluid (wind) was blown from a turbo fan $(220 \mathrm{~V} / 50 \mathrm{~Hz}-98 \mathrm{~W})$. In this research, the correlations between the wind velocity as a function of the generator's angular speed, output voltage (with and without the use of LED lamp: $5 \mathrm{~W}$ ), the current and the power produced by the generator were analysed. The performances of the permanent magnet generator system suggested linears trend in the angular speed, the output voltage, the current and the power produced. The correlations show that the optimum condition can be achieved at the wind velocity of $6,5 \mathrm{~m} / \mathrm{s}$ with 16 blades that generates the angular speed, the ouput voltage (with and without led lamp,) the current and the power: $120 \mathrm{rpm}, 44,3 \mathrm{~V}, 109,8 \mathrm{~V}, 100 \mathrm{~mA}$ and $4 \mathrm{~W}$, respectively. The single phase permanent magnet $(\mathrm{NdFeB})$ generator can be used as an emergency lamp, particularly on the highway road.
\end{abstract}

Keywords: turbine blade, NdFeB magnet, single phase generator, wind velocity, electric power

\section{PENDAHULUAN}

Pembangkit listrikdi Indonesia umumnya masih menggunakan bahan bakar fosil, seperti: PLTU, PLTG dan PLTGU. Untuk mengurangi penggunaan bahan bakar fosil tersebut maka dibutuhkan sumber energi alternatif, seperti energi baru dan terbarukan sebagai penghasil listrik [1]. Pemanfaatan energi air dan angin dalam pembangkitan energi listrik telah banyak dilakukan baik dalam skala besar maupun dalam skala mikro/piko [1]. Indonesia memilikpotensi air dan angin yang cukup besar terkait dengan bidang energi, dapat dipasang di pulaupulau kecil dan terluar di Indonesia. Khususnya energi angin, kecepatan angin yang tidak stabil dan berubah- 
ubah memerlukan batere atau media penyimpanan lainnya. Prinsip dari pembangkit listrik tenaga angin adalah mengubah energi kinetik dari sudu-sudu turbin yang berputar akibat kecepatan angin sehingga memutar generator dan menghasilkan listrik [2]. Dalam rangka memanfaatkan potensi angin ini maka perlu dibuat desaindan konstruksi turbin angin, salah satu desainnya adalah tipe Savonius yang mampu menghasilkan energi listrik yang lebih optimal [3, 5-6]. Salah satu yang mempengaruhi kinerja generator single phase adalah jumlah sudu turbin. Pada penelitian ini akan dilakukan rancang bangun dan ekperimen tentang pengaruh jumlah sudu turbin 4, 8, dan 16 buah terhadap kinerja generator single phase dengan menggunakan magnet permanen NdFeB. Contoh model turbin angin Savonius Vertical Axis Wind Turbine (VAWT) diperlihatkan pada Gambar 1 $[3,4]$.

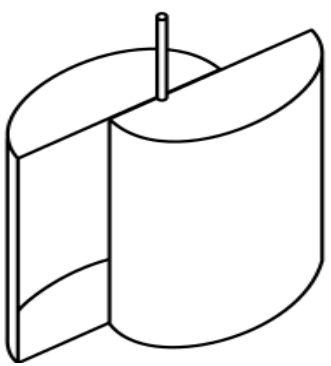

$\mathbf{a}$

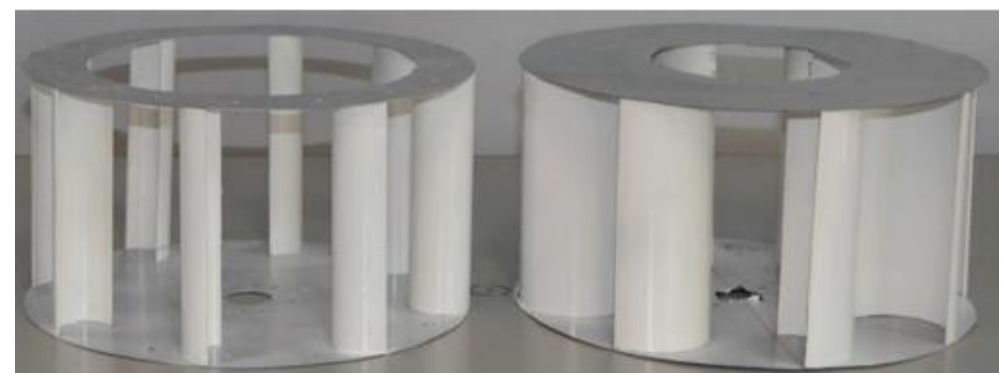

b

Gambar 1. a). Model turbin angin Savonius b). Vertical Axis Wind Turbine (VAWT) $[3,4]$.

Rotor merupakan komponen utama dari generator dimana didalamnya terdapat susunan magnet permanen. Magnet permanen yang akan digunakan dapat berupa barium heksaferite atau bonded NdFeB, biasanya digunakan sebagai material rotor agar beratnya menjadi lebih ringan [7-10]. Sedangkan stator terdiri dari susunan lilitan koil berbahan tembaga/material lainnya bersifat konduktor dan merupakan komponen generator yang statis (kebalikan dari rotor). Susunan koil tersebut dicetak juga menggunakan material resin atau epoksi. Contoh rotor dan stator yang biasanya digunakan dalam sistem generator diperlihatkan pada Gambar 2 [11-15].

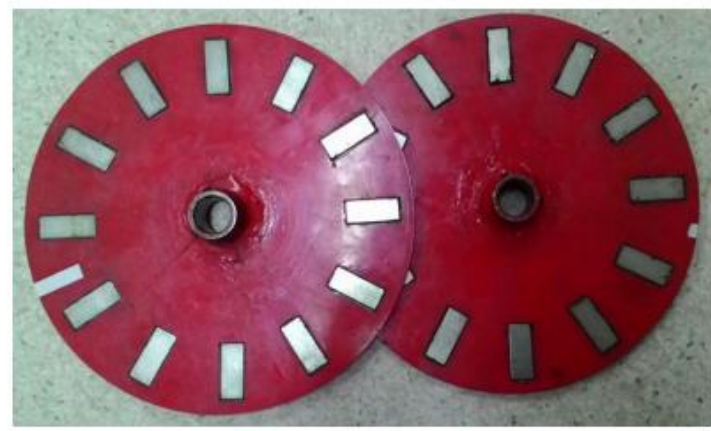

$\mathbf{a}$

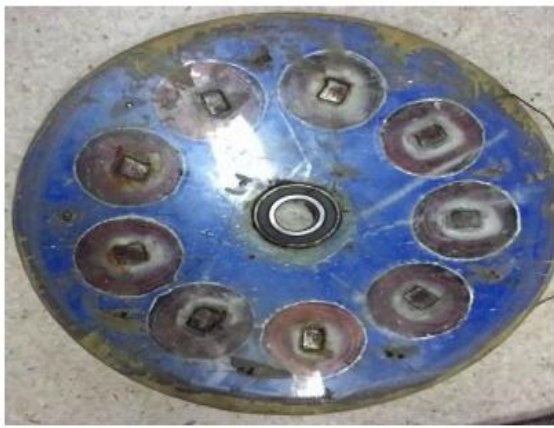

$\mathbf{b}$

Gambar 2. Sistem generator yang dikembangkan oleh Pusat Penelitian Fisika-LIPI. a). Rotor dan b). Stator [10-14]

\section{METODOLOGI}

Disain dan skematik pengujian turbin angin savonius dan generator listrik (single phase) magnet permanen (NdFeB) yang digunakan pada penelitian ini diperlihatkan pada Gambar 3. Turbin angin tersebut dibuat dengan spesifikasi sebagai berikut: bahan sudu turbin terbuat dari pipa paralon dengan diameter $10 \mathrm{~cm}$, panjang $50 \mathrm{~cm}$ (Gambar 4). Jumlah sudu turbin masing-masing dibuat 4, 8 dan 16 buah yang merupakan parameter penelitian, sedangkan besaran lainnya dibuat tetap. Beban kerja pada generator listrik (single phase) magnet permanen $(\mathrm{NdFeB})$ adalah lampu $L E D 5 \mathrm{~W}$. Untuk pengukuran kecepatan angin digunakan anemometer dan pengukuran kecepatan putar generator listrik single phase diukur dengan tachometer. Pengukuran output tegangan generator listrik single phase tanpa dan dengan beban lampu LED $5 \mathrm{~W}$ serta arus listrik dilakukan dengan menggunakan multimeter. 


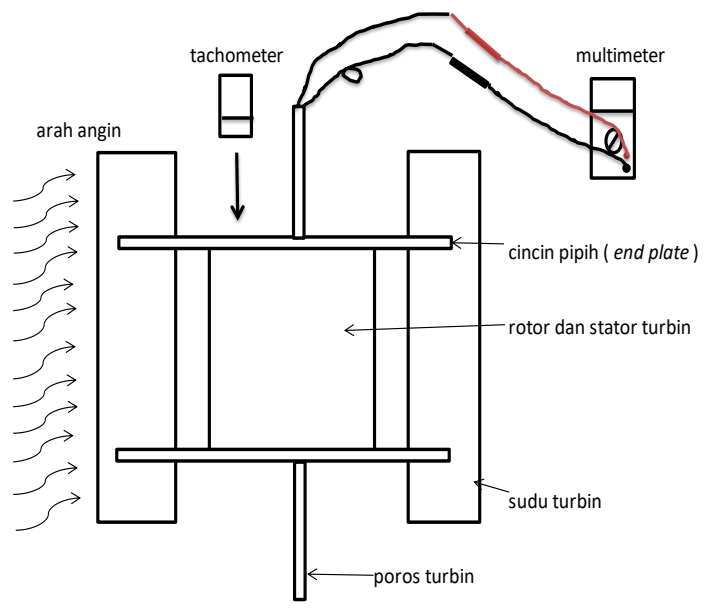

a

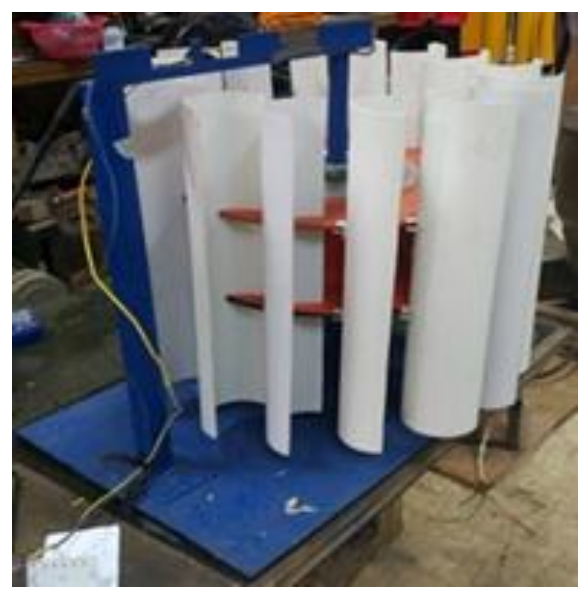

b

Gambar 3. a). Disain dan skematik turbin angin savonius dan b). Generator listrik (single phase) magnet permanen (NdFeB).

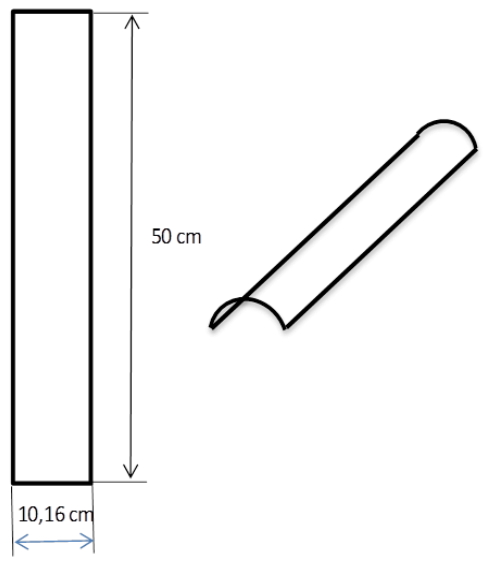

a

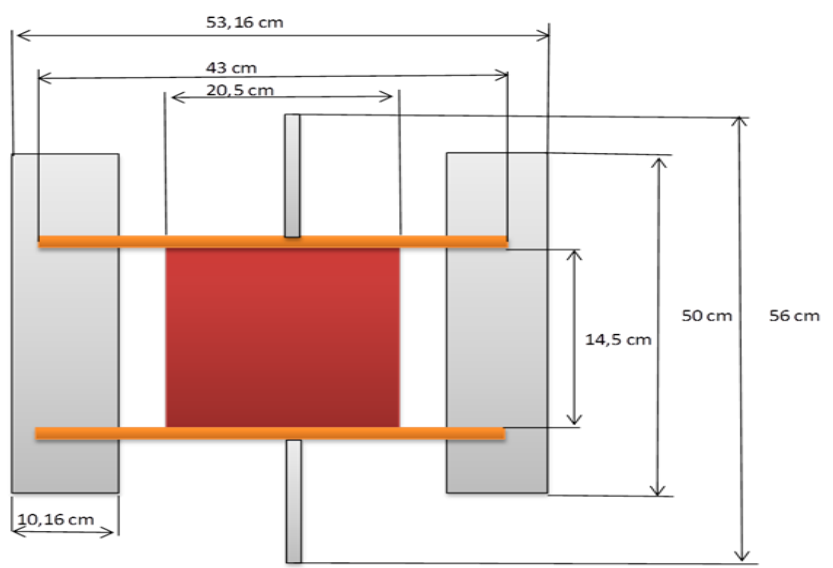

b

Gambar 4. a). Konstruksi turbin angin savonius dan b). Generator listrik (single phase) magnet permanen (NdFeB).

\section{HASIL DAN PEMBAHASAN}

Pada Gambar 5, menunjukkan bahwa korelasi antara kecepatan angin terhadap kecepatan putar dari generator adalah berbanding lurus. Artinya semakin besar angin yang diterima sudu turbin maka kecepatan putar generator listrik juga cenderung meningkat. Demikian pula halnya semakin banyak jumlah sudu turbin yang digunakan maka semakin besar volume udara yang diterima oleh sudu turbin tersebut, akibatnya kecepatan putar generator juga akan semakin tinggi. Pada jumlah sudu turbin sebanyak 4 buah memenuhi persamaan garis $\mathrm{Y}=4,47 \mathrm{X}+60,87$, sedangkan pada jumlah sudu turbin sebanyak 8 buah memenuhi persamaan garis, $\mathrm{Y}=1,62 \mathrm{X}$ $+84,1$ dan pada jumlah sudu turbin sebanyak 16 buah memenuhi persamaan garis, $\mathrm{Y}=4,61 \mathrm{X}+80,37$. Dari persamaan di atas dimana $\mathrm{Y}=$ kecepatan putar generator listrik dan $\mathrm{X}$ adalah kecepatan angin. Apabila dilihat dari kurva di atas menunjukkan adanya pola yang hampir sama antara jumlah sudu turbin 4 dan 16 buah, dengan slope $(\mathrm{m})$ sebesar 4,4 dan 4,6. Berbeda pada jumlah sudu turbin 8 buah, dimana slope yang diperoleh relatif landai dengan $\mathrm{m}=1,62$.

Pada penelitian sebelumnya, Loganathan, et.al, 2017 [16] diperoleh kecepatan putar maksimum $220 \mathrm{rpm}$ pada kecepatan angin $8,5 \mathrm{~m} / \mathrm{s}$ dengan 8 sudu turbin (diameter $8 \mathrm{~cm}$ dan panjang $16 \mathrm{~cm}$ ). Sedangkan pada penelitian ini pada kondisi jumlah sudu turbin yang sama ( 8 buah), kecepatan putar yang dihasilkan mencapai $105 \mathrm{rpm}$ pada kecepatan angin yang lebih kecil: $6,5 \mathrm{~m} / \mathrm{s}$ dengan dimensi sudu turbin (diameter $10 \mathrm{~cm}$ dan panjang $50 \mathrm{~cm})$. 


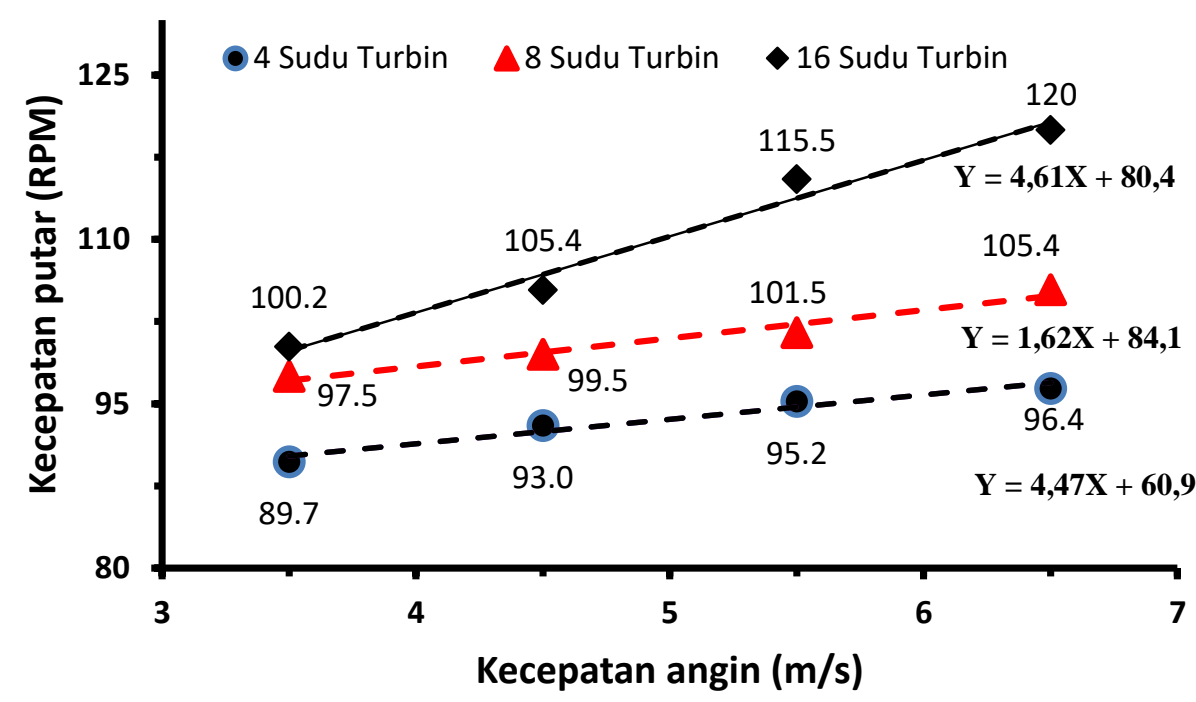

Gambar 5. Korelasi antara kecepatan angin terhadap kecepatan putardari Generator fluks aksial.

Dari Gambar 6, diperlihatkan bahwa hubungan antara kecepatan angin terhadap output tegangan generator fluks aksial tanpa beban adalah berbanding lurus. Kurva yang dihasilkan masing-masing 4, 8, dan 16 sudu turbin memenuhi persamaan sebagai berikut: $\mathrm{V}=1,5 \mathrm{X}+26, \mathrm{~V}=1,34 \mathrm{X}+30,8$ dan $\mathrm{V}=2,66 \mathrm{X}+26,7$, dimana $\mathrm{V}=$ output tegangan generator dan $\mathrm{X}=$ kecepatan angin. Apabila dilihat dari hasil slope $(\mathrm{m})$ yang diperoleh untuk jumlah sudu turbin 4 dan 8 buah memiliki tren yang sama, berbeda dengan jumlah sudu turbin 16 buah. Akan tetapi apabila dilihat dari nilai slope untuk jumlah sudu turbin 8 dan 16 buah memiliki kelipatan 2, artinya ada korelasi tertentu atau tetap dan hal ini berbeda dengan 4 buah sudu turbin Savonius.

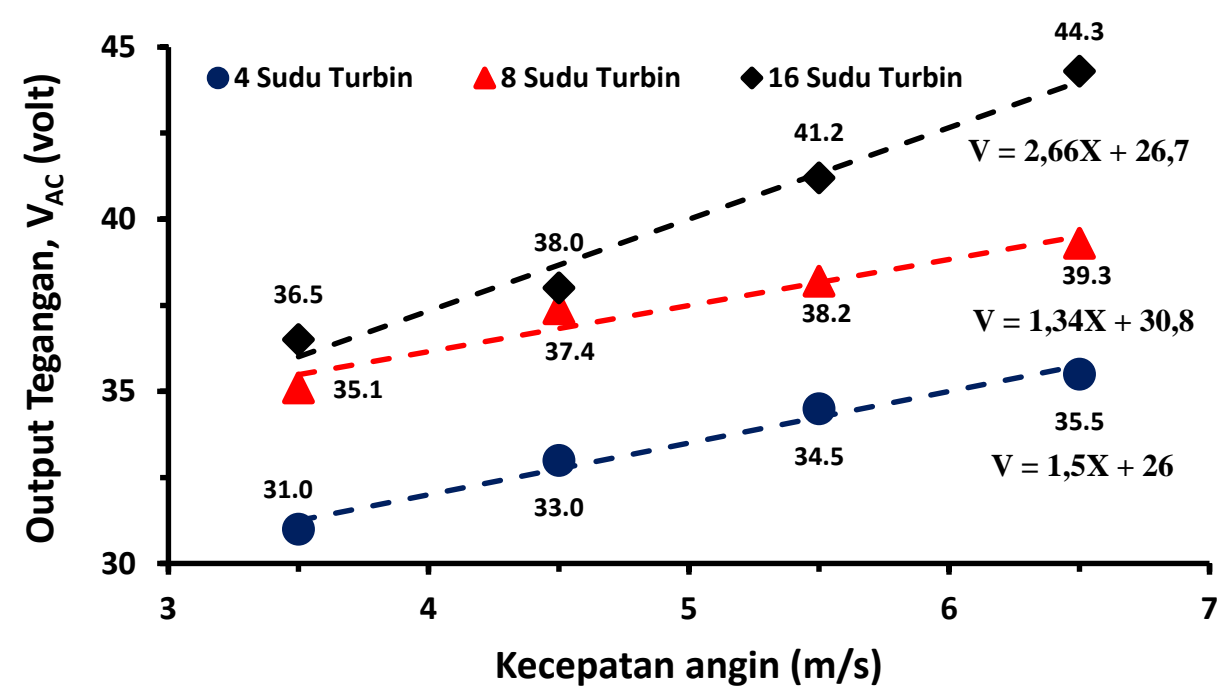

Gambar 6. Korelasi antara kecepatan angin terhadap output tegangan dari Generator fluks axial tanpa beban.

Pada Gambar 7, ditunjukkan korelasi antara kecepatan angin terhadap output tegangan generator fluks aksial dengan beban lampu LED 5 W. Korelasi ini juga menunjukkan hubungan liner dari masing-masing 4, 8, dan 16 sudu turbin yang memenuhi persamaan garis sebagai berikut: $\mathrm{V}=4,47 \mathrm{X}+61, \mathrm{~V}=1,62 \mathrm{X}+84$ dan $\mathrm{V}=$ $4,61 \mathrm{X}+80,4$, dimana $\mathrm{V}=$ output tegangan generator dengan beban lampu LED 5W dan $\mathrm{X}=$ kecepatan angin. Apabila dilihat dari hasil slope $(\mathrm{m})$ yang diperoleh untuk jumlah sudu turbin 4 dan 16 buah memiliki tren yang sama, yaitu dengan nilai $\mathrm{m}=4,47$ dan 4,61 . Sedangkan pada 8 sudu turbin menghasilkan nilai $\mathrm{m}=1,62$, artinya relatif lebih landai. 


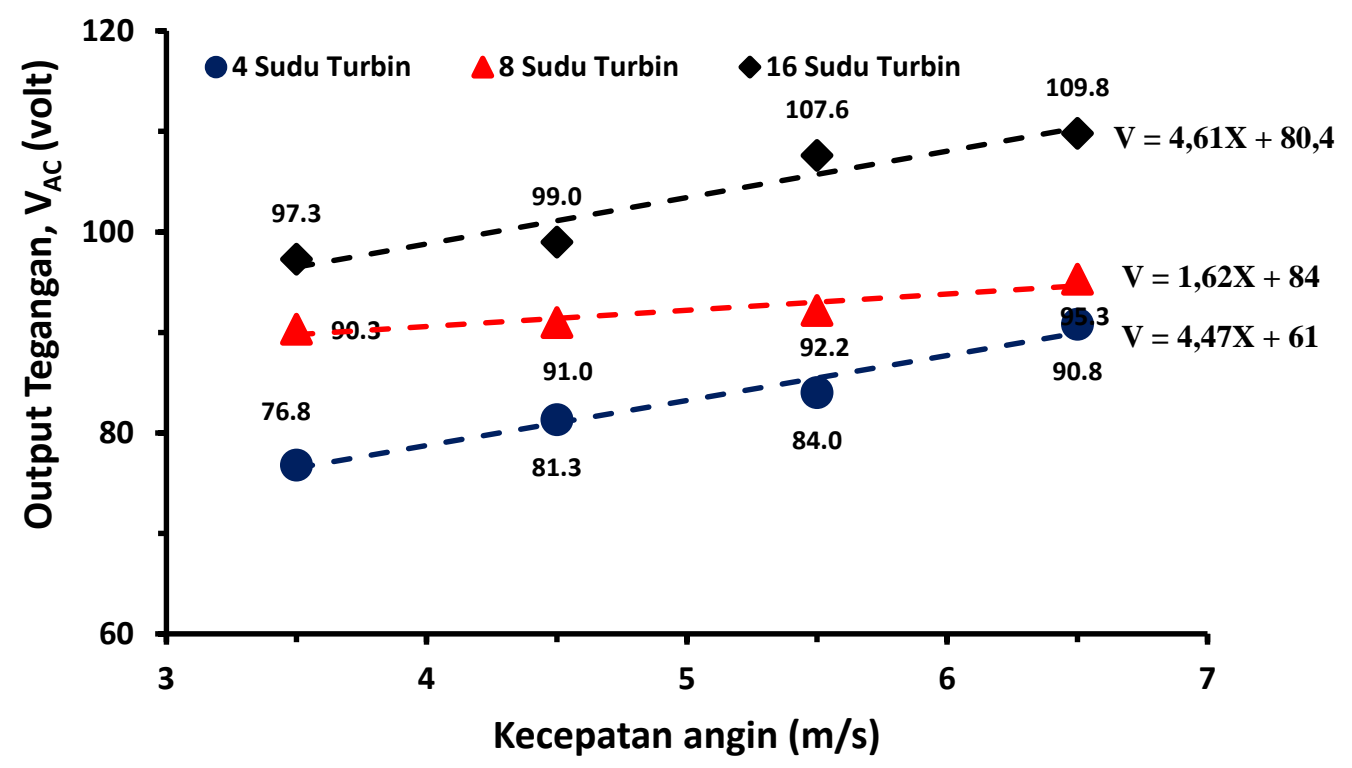

Gambar 7. Korelasi antara kecepatan angin terhadap output tegangan Generator fluks axial dengan beban lampu LED 5 W.

Pada Gambar 8, ditunjukkan korelasi antara kecepatan angin terhadap arus listrik dari generator fluks aksial dengan beban lampu LED 5W. Korelasi ini juga menunjukkan korelasi linier dari masing-masing 4, 8, dan 16 sudu turbin yang memenuhi persamaan garis sebagai berikut: $\mathrm{I}=0,01 \mathrm{X}-0,015, \mathrm{I}=0,006 \mathrm{X}+0,03$ dan $\mathrm{I}=0,01 \mathrm{X}$ $+0,034$, dimana $\mathrm{I}=$ arus listrik dari generator dengan beban lampu LED $5 \mathrm{~W}$ dan $\mathrm{X}=$ kecepatan angin. Apabila dilihat dari hasil slope $(\mathrm{m})$ yang diperoleh untuk jumlah sudu turbin 4 dan 16 buah memiliki tren yang sama, yaitu dengan nilai $\mathrm{m}=0,01$. Sedangkan pada 8 sudu turbin menghasilkan nilai $\mathrm{m}=0,006$, artinya relatif lebih landai.

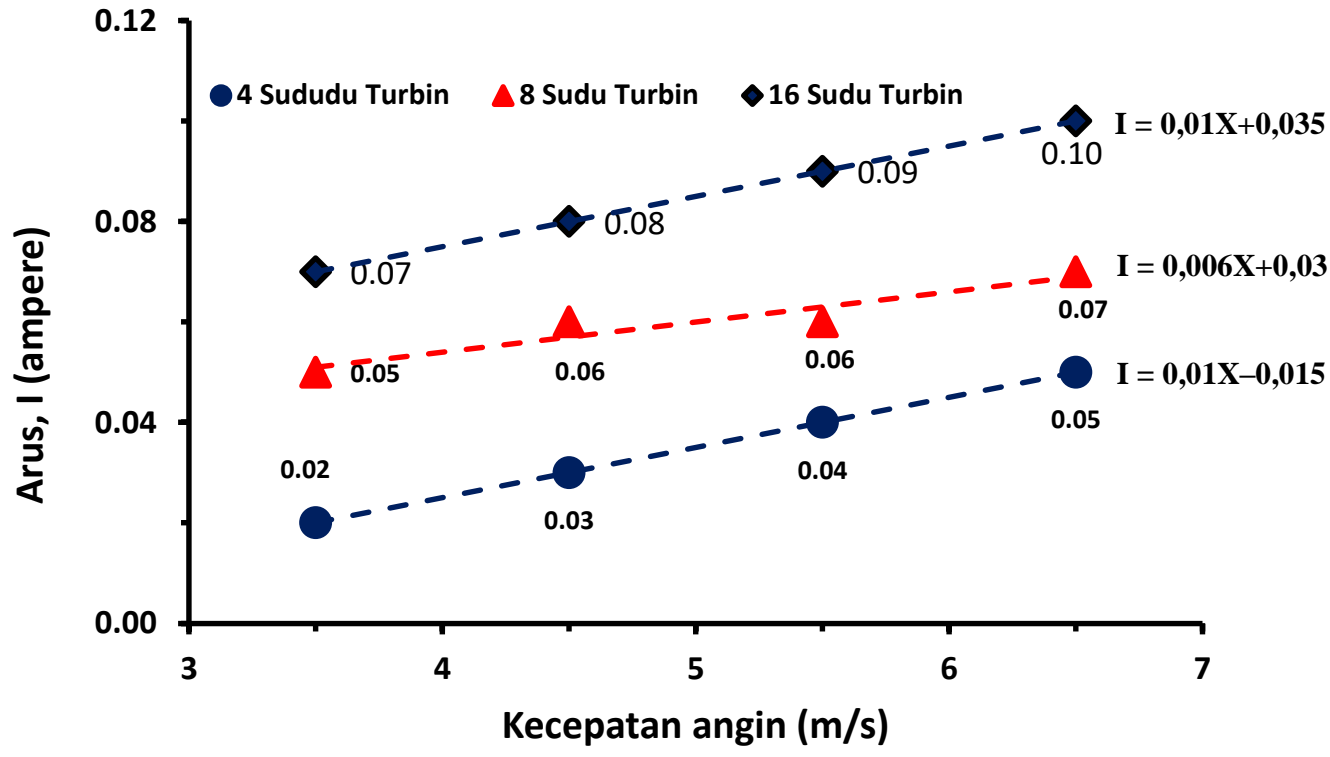

Gambar 8. Korelasi antara kecepatan angin terhadap arus listrik Generator fluks axial dengan beban lampu LED 5 W.

Pada Gambar 9, ditunnjukkan korelasi antara kecepatan angin terhadap daya listrik dari generator fluks aksial dengan beban lampu LED $5 \mathrm{~W}$. Korelasi ini juga menunjukkan hubungan liner dari masing-masing 4, 8, dan 16 sudu turbin yang memenuhi persamaan garis sebagai berikut: $\mathrm{P}=0.342 \mathrm{X}-0.675, \mathrm{P}=0.268 \mathrm{X}+0.635$ dan $\mathrm{P}=0.51 \mathrm{X}+0.7$, dimana $\mathrm{P}=$ daya listrik yang dihasilkan generator dengan beban lampu LED $5 \mathrm{~W}$ dan $\mathrm{X}=$ kecepatan angin. Apabila dilihat dari nilai slope (m) yang diperoleh untuk jumlah sudu turbin 4, 8, dan 16 buah memiliki tren yang berbeda, yaitu maasing-masing dengan nilai $\mathrm{m}=0,342 ; 0,268$; dan 0,51 . 


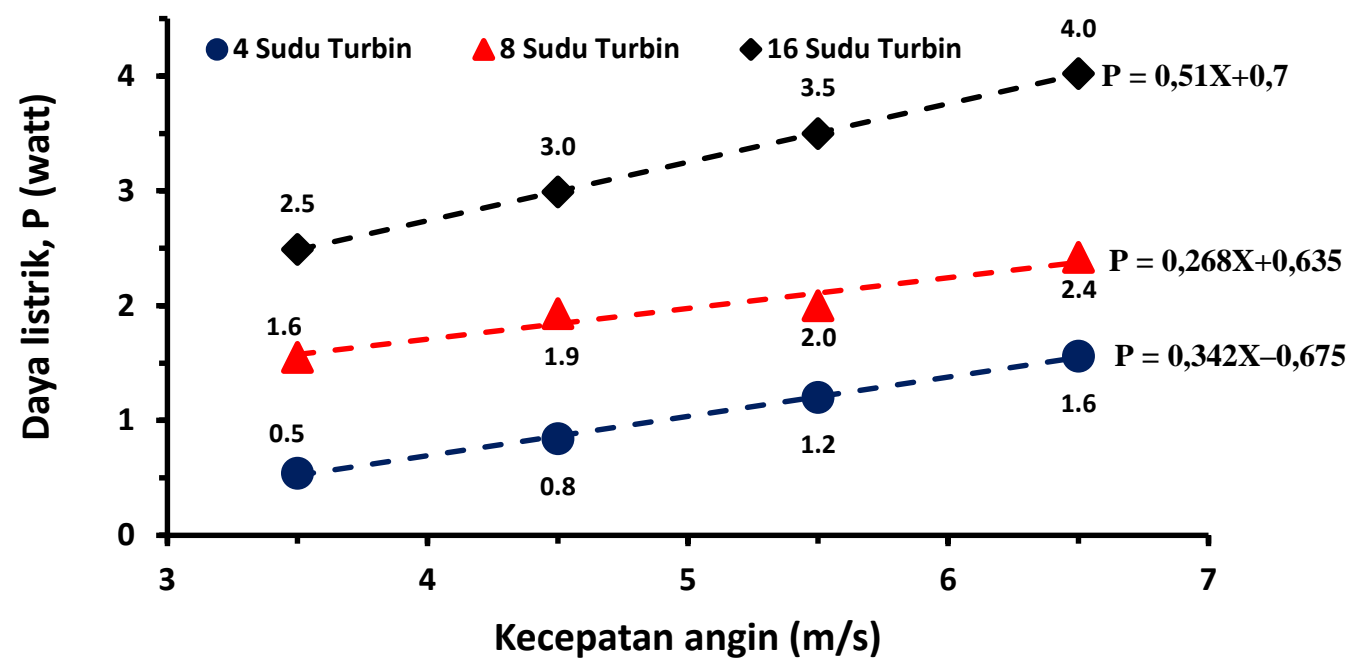

Gambar 9. Korelasi antara kecepatan angin terhadap daya listrik dari Generator fluks axial dengan beban lampu LED 5 W.

Hasil penelitian ini menunjukkan kinerja yang lebih baik karena daya listrik yang dihasilkan dapat mencapai $4 \mathrm{~W}$ dengan 16 sudu turbin (diameter $10 \mathrm{~cm}$ dan panjang $50 \mathrm{~cm}$ ) pada kecepatan angin $6,5 \mathrm{~m} / \mathrm{s}$. Dimana pada penelitian sebelumnya oleh Loganathan, et.al, 2017[16], diperoleh daya listrik yang lebih kecil, yaitu $1,5 \mathrm{~W}$ dengan kondisi 8 sudu turbin (diameter $8 \mathrm{~cm}$ dan panjang $16 \mathrm{~cm}$ ) serta kecepatan angin $8,5 \mathrm{~m} / \mathrm{s}$. Hal tersebut menunjukkan bahwa parameter-parameter pada sistem sudu turbin angin-generator adalah scalable factor. Perbesaran dimensi sudu (diameter dan panjang) akan berpengaruh pada besarnya energi kinetik dari angin yang diterima sudu turbin. Dengan demikian kecepatan angin dan bentuk sudu turbin berdampak pada putaran generator untuk menghasilkan tegangan luaran dan daya listrik yang dihasilkan.

\section{KESIMPULAN}

Telah berhasil dibuat disain dan konstruksi generator magnet permanen NdFeB single phase dengan jumlah sudu turbin angin savonius masing-masing sebanyak 4, 8, dan 16 buah. Hasil unjuk kerja generator magnet permanen NdFeB single phase terhadap pengaruh jumlah sudu turbin relatif linier baik terhadap kecepatan putar generator, output tegangan, arus dan daya listrik yang dihasilkan. Korelasi ini menunjukkan bahwa kondisi optimum diperoleh pada kecepatan angin $6,5 \mathrm{~m} / \mathrm{s}$ dan jumlah sudu turbin sebanyak 16 buah, masing-masing menghasilkan kecepatan putar generator, output tegangan tanpa dan dengan beban, arus dan daya listrik adalah $120 \mathrm{rpm} ; 44,3 \mathrm{~V} ; 109,8 \mathrm{~V} ; 100 \mathrm{~mA}$ dan $4 \mathrm{~W}$. Generator magnet permanen NdFeB single phase yang dihasilkan ini dapat digunakan sebagai lampu darurat di jalan tol, terutama pada daerah tikungan dan licin.

\section{DAFTAR PUSTAKA}

[1] Daryanto Y 2007 Kajian Potensi Angin Untuk Pembangkit Listrik Tenaga Bayu (Balai PPTAGG-UPTLAGG)

[2] Gieras J F, Wang R J dan Kamper M J 2008 Axial Flux Permanent Magnet Brushless Machines, 2nd ed. (Springer)

[3] SahaUK dan RajkumarMJ 2006 Renewable Energy 311776

[4] Loganathan B, Mustary I, Chowdhury H dan Alam F 2017 Energy Procedia 110555

[5] Mohamed Hassan Ahmed Mohamed 2011 Design Optimization of Savonius and Wells Turbines Dissertation, University of Magdeburg

[6] Davila-Vilchis J M dan Mishr R S 2014 Energy 65631

[7] Muljadi, Sardjono P dan Suprapedi 2015 Energy Procedia 68282

[8] Gargov N P, Zobaa A F dan Pisica I 2014 Electric Power Systems Research 10963

[9] Ahmed D dan Ahmad A 2013 Journal of Physics: Conference Series 439012039

[10] Feiand W dan Luk P C K. 2009 Proc. IEEE int. Eletric Machines \& Drives conf. p 1

[11] Soehada A M, Sebayang P dan Kurniawan C 2017 Piston 16 
[12] Simbolon S, Tetuko A P, Sebayang K dan Sebayang P 2017 Piston 11

[13] Nurdiyansyah L F, Tetuko A P, Aryanto D dan Sebayang P 2016 Telaah 329

[14] Tetuko A P, Kurniawan C dan Sebayang P 2013 Simulasi Flux Density Permanent Magnet NdFeB untuk Aplikasi Generator Listrik Prosiding Seminar Nasional Kimia Terapan Indonesia (Solo) p 85

[15] Yanti Y, Nurdiyansah L F, Tetuko A P, Siregar M R T dan Sebayang P 2013 Rancang Bangun Generator Mini Tipe Aksial Dengan Menggunakan Magnet Permanen NdFeB dan Kajiannya, Seminar dan Focus Group Discussion (FGD) Material Maju: Magnet dan Aplikasinya.

[16] Loganathan B, Mustary I, Chowdhury H dan Alam F 2017 Energy Procedia 110555 